\title{
RESISTANSI TERHADAP PENYIMPANGAN KEKUASAAN DALAM TIGA CERPEN KALIMANTAN TIMUR
}

\section{RESISTANCE TO POWER DEVIATION IN THREE EAST KALIMANTAN'S SHORT STORIES}

\author{
Aquari Mustikawati \\ Kantor Bahasa Kalimantan Timur \\ Jalan Batu Cermin 25, Sempaja Utara, Samarinda \\ Pos-el: sunburn_4s@yahoo.co.id
}

*) Naskah diterima: 13 November 2019; direvisi: 4 Desember 2019; disetujui: 5 Desember 2019

\begin{abstract}
Abstrak
Penelitian ini menunjukkan gambaran resistansi terhadap penyimpangan kekuasaan pemegang kekuasaan dalam tiga cerpen Kalimantan Timur, yaitu "Banjirkap", "Poniran" dan "Kota ini telah Terjual". Masalah yang difokuskan dalam penelitian ini adalah bagaimana bentuk resistansi dan penyimpangan kekuasaan dalam tiga cerpen tersebut. Untuk memecahkan masalah dan mencapai tujuan digunakan metode kualitatif yang memperhatikan data alamiah sehingga penelitian dapat melibatkan sejumlah gejala sosial yang relevan, termasuk unsur-unsur kebudayaan. Dengan menggunakan teori resistansi Scott, tulisan ini menganalisis bentuk-bentuk penyimpangan kekuasaan yang memarginalkan masyarakat. Hasil pembahasan menunjukkan bahwa tokoh di tiga cerita pendek tersebut melakukan resistansi terhadap penyimpangan kekuasaan yang berbentuk aksi penindasan terhadap masyarakat marginal. Berdasarkan pembahasan, penelitian ini menyimpulkan bahwa relasi kekuasaan adalah suatu bentuk legalitas untuk menindas masyarakat marginal. Relasi kekuasaan tersebut merupakan suatu ikatan yang saling menguntungkan.
\end{abstract}

Kata kunci: resistansi, penyimpangan kekuasaan, gejala sosial, cerpen

\begin{abstract}
This study reveals of resistance to power deviations from power holders in three short stories in East Kalimantan, namely "Banjirkap", "Poniran" and "Kota ini telah Terjual". The problem of this research is focused on what is the form of resistance and power deviation in the three short stories. To solve problems and achieve goals, qualitative methods are used that concern about original data that's include of relevant social phenomena and cultural elements. Using Scott's resistance theory, this paper analyzes resistance to power deviations against marginal society. The results of the discussion show that the characters in the three short stories resist the power deviations by abusing their power as oppression against marginalized communities. Based on the discussion, this study concludes that power relations are a form of legality to oppress marginal communities, but are a mutually beneficial bond.
\end{abstract}

Keywords: resistance, power deviation, social phenomenon, short stories 


\section{PENDAHULUAN}

Provinsi Kalimantan Timur adalah suatu wilayah yang sangat menarik untuk diamati. Kalimantan Timur memiliki potensi hayati yang sangat beragam, terutama hutan kayu yang sangat terkenal. Sementara itu, potensi lainnya adalah sumber daya alam yang terdapat di dalam tanah berupa sumber tambang, seperti minyak, batu bara, gas, dan masih banyak lagi. Potensi lainnya adalah potensi budaya, yaitu keanekaragaman suku dan budaya yang ada di Provinsi Kalimantan Timur, seperti masyarakat Dayak dan budayanya yang sangat unik.

Beragam potensi yang dimiliki Kalimantan Timur menjadikan provinsi ini menjadi primadona yang menarik bagi pendatang dan investor dari daerah lain untuk ikut menikmati potensi tersebut. Salah satu masa keemasan di Kalimantan Timur adalah masa eksploitasi kayu gelondongan dari pedalaman yang dikenal dengan istilah banjirkap.

Istilah banjirkap pada tahun 1970-an sampai dengan 1980-an sangat populer di Kalimantan Timur. Pada masa itu masyarakat sangat antusias menyambut kegiatan banjirkap karena janji imbalan yang lebih menggiurkan dari pendapatan mereka sebagai petani, buruh atau pun aparatur sipil negara. Istilah banjirkap merupakan kegiatan pengiriman kayu gelondongan hasil penebangan yang dihanyutkan melalui sungai dari daerah hulu sungai ke daerah hilir tempat pabrik pengolahan kayu. Kotijah (2010: https://gagasanhukum.wordpress. com/2010/03/18/banjir-kap-batubarakaltim/) menyebutkan istilah banjirkap sebagai sistem penebangan yang sistematis di seluruh wilayah Kalimantan Timur dengan sentra alat transportasi utama Sungai Mahakam sebagai lalu lintas kayu-kayu hutan Kalimantan tersebut sebelum diangkut ke Jawa, Sulawesi, Malaysia, Cina, dan
Jepang. Hal itu membuktikan bahwa sistem penebangan kayu gelondongan secara sistematis dan besar-besaran untuk ekspor tersebut telah terjadi di Kalimantan Timur dan menimbulkan masalah alam dan sosial.

Selain kayu, pada masa-masa itu ditemukan beberapa sumber minyak dan batu bara yang menarik investor dari daerah lain untuk ikut menanam modal dan melakukan aktivitas penambangan. Kegiatan tersebut berlangsung selama beberapa tahun. Kedatangan masyarakat yang memiliki perbedaan latar belakang pada masa-masa tersebut tidak luput dari berbagai pergolakan sosial. Konflik yang berkembang meliputi konflik penguasa dan bawahan, konflik pendatang dan masyarakat atau penduduk asli. Hal itu disebabkan karena kerakusan penguasa yang memiliki kekuatan untuk menindas masyarakat.

Kejadian-kejadian berupa konflik sosial terekam dalam karya sastra yang pernah terbit di Kalimantan Timur. Tiga cerita pendek, yaitu "Banjirkap", "Poniran" dan "Kota ini telah Terjual" menceritakan konflik sosial akibat kerakusan pihak yang berkuasa. Pihak yang berkuasa melakukan bentukbentuk penyimpangan kekuasaan sehingga menyebabkan kerugian orang-orang marginal. Tokoh-tokoh marginal yang merupakan tokoh utama dalam tiga cerita pendek tersebut melakukan beberapa bentuk resistansi terhadap penyimpangan kekuasaan tersebut. Berdasarkan hal tersebut rumusan masalah dalam penelitian ini adalah (1) bagaimana bentuk perlawanan tokoh marginal dalam tiga cerita pendek tersebut berdasarkan teori resistansi Scott? Bagaimana bentuk penyimpangan kekuasaan dalam ketiga cerita pendek tersebut? Sementara itu, tujuan penelitian ini adalah (1) untuk mengetahui bentuk perlawanan tokoh dalam tiga cerita pendek "Banjirkap", "Poniran" dan "Kota in telah Terjual" sesuai dengan teori resistansi 
Scott dan (2) untuk mengetahui bentuk penyimpangan kekuasaan dalam tiga cerita pendek tersebut.

\section{TEORI}

Arti kata resistansi secara harfiah adalah perlawanan atau menentang. Kata ini secara etimologi berasal dari bahasa Inggris, yaitu resist. Kata resist berarti semua tindakan menolak atau melawan hal yang tidak mereka setujui. Scott (2000:385-386) memberi batasan pengertian resistansi secara umum dengan melihat situasi di masyarakat yang sebenarnya. Resistansi menurutnya dapat diartikan sebagai sesuatu yang bersifat (1) organik, sistematis, dan kooperatif, (2) berprinsip dan tidak mementingkan diri sendiri, (3) berkonsekuensi revolusioner, dan (3) mencakup gagasan atau maksud-maksud yang menpasiiadakan basis belakang seputar kehidupan keluarga. Resistansi menurut Scott dapat dibedakan menjadi dua kategori, yaitu resistansi yang disebabkan oleh penyebab secara langsung atau terbuka dan penyebab tidak langsung atau tersembunyi.

Menurut James Scott dalam Susilowati (2019:5), terdapat dua bentuk resistansi, yaitu (a) resistansi terbuka adalah bentuk resistansi yang terorganisasi, sistematis, dan berprinsip, biasanya berbentuk protes sosial atau demonstrasi yang lebih ke arah pemberontakan, (b) resistansi tertutup merupakan penolakan terhadap hal-hal yang dipaksakan berupa simbolis atau ideologis.

Secara umum, resistansi atau perlawanan terjadi karena pemaksaan atau penindasan terhadap kaum subordinat. Perlawanan yang mereka lakukan untuk membela hak mereka.

\section{METODE}

Metode yang digunakan dalam penelitian ini adalah metode kualitatif. Metode kualitatif memberikan perhatian terhadap data alamiah sehingga penelitian dapat melibatkan sejumlah gejala sosial yang relevan, termasuk unsur-unsur kebudayaan (Ratna, 2008:47). Penelitian kualitatif melakukan penelitian berawal dari hal-hal umum yang sudah diketahui dan tidak dapat dinyatakan dalam hipotesis. Data alamiah yang dimaksud adalah pengetahuan umum dan gejala sosial yang telah diketahui. Goldmann (1970:588-181) mengatakan bahwa semua fakta kemanusiaan sebagai struktur yang berarti. Penjelasan ini menguatkan pendapat Ratna (2008:46-47) mengungkapkan bahwa fakta kemanusiaan secara sosiologis dapat dikatakan sebagai usaha manusia mencapai keseimbangan dalam hubungannya dengan kehidupan sekitarnya.

Fakta kemanusiaan atau data alamiah yang dimaksud peneliti adalah persoalan penyimpangan kekuasaan yang terdapat dalam tiga cerita pendek, yaitu "Banjirkap", "Poniran" dan "Kota ini telah Terjual". Tahapan-tahapan analisis penelitian ini dilakukan sebagai berikut (1) menemukan data alamiah atau fakta kemanusiaan berupa penyimpangan kekuasaan dan resistansi penyimpangan kekuasaan dalam objek berupa tiga cerita pendek, (2) identifikasi resistansi berdasarkan bentuk penyimpangan kekuasaan, (3) analisis resistansi penyimpangan kekuasaan untuk menentukan bentuk resistansi sesuai dengan teori James C. Scott, dan (4) menyimpulkan sebab akibat resistansi sebagai hubungan penyimpangan kekuasaan.

Pendekatan yang dilakukan dalam tulisan ini ialah sosiologi sastra. Goldmann dalam Faruk (1994:87) menjelaskan bahwa sosiologi sastra menekankan teks sastra sebagai suatu struktur yang koheren. 


\section{HASIL DAN PEMBAHASAN}

\section{Sinopsis "Banjirkap", "Poniran" dan "Kota ini telah Terjual"}

Tiga cerita pendek yang menjadi objek penelitian ini adalah "Banjirkap", "Poniran" dan "Kota ini telah Terjual". Cerita pendek yang pertama adalah karya Habolhasan Asyari dan dimuat ulang di antologi Kalimantan Timur dalam Sastra Indonesia pada tahun 2011. Latar cerita tersebut adalah Kalimantan Timur pada masa banjirkap, yaitu sekitar tahun 1970-an sampai dengan 1980an. Cerita pendek tersebut menceritakan seorang laki-laki bernama Parhan. Ia adalah seorang petani yang bertempat di daerah aliran sungai Mahakam.

Pada masa banjirkap, ia beralih profesi menjadi seorang penebang pohon di hutan pedalaman Kalimantan. Tidak hanya Parhan, hampir seluruh laki-laki di kampungnya beralih profesi seperti Parhan. Hal itu dilakukan karena penghasilan dari menebang pohon tersebut jauh lebih banyak daripada bekerja sebagai petani. Kehidupan sebagai penebang pohon di hutan pedalaman Kalimantan tidaklah mudah. Mereka harus tinggal selama berbulan-bulan di hutan dan jauh dari keluarga. Sebagai laki-laki normal godaan yang paling berat adalah pelampiasan hasrat biologis. Selama ini Parhan masih dapat mengendalikan dirinya. Ia selalu teringat istrinya Imas dan anaknya Juray yang baru berusia 5 tahun. Istri dan anaknya dengan setia menunggu Parhan di Desa Tanjung Haur. Walaupun teman-teman Parhan seringkali turun ke Kampung Muara dan melampiaskan hasrat mereka pada penjaja cinta sesaat di daerah tersebut, Parhan berusaha menjaga jangan sampai ia terpengaruh teman-temannya. Pernah suatu kali Parhan hampir terpeleset. Ia sudah berduaaan di dalam kamar bersama Sumi, seorang pelacur di Kampung Muara. Akan tetapi, lagi-lagi Parhan teringat istri dan anaknya, sehingga semalaman ia hanya berbincang-bincang dengan Sumi.

Di Kampung Muara juga ada anemer (pemilik modal) bernama Pak Joh. Para penebang menjual kayunya pada Pak Joh. Pak Joh juga tidak keberatan bertugas sebagai pengantar surat dari para penebang keluarga mereka dan sebaliknya. Salah seorang yang sering memanfaatkan jasa Pak Joh adalah Parhan. Ia sering menerima surat dari Imas melalui Pak Joh. Melalui surat tersebut komunikasi Parhan dengan Imas dapat berjalan dengan lancar. Dalam suratnya, Imas menyebutkan bahwa uang hasil jerih payah Parhan telah diwujudkan dalam bentuk barang-barang mewah dan tabungan yang jumlahnya puluhan juta. Pada suatu hari teman Parhan sesama penebang pohon, Undat, mendadak sakit. Menurut masyarakat setempat sakitnya adalah kapuhunan, yaitu sakit karena melanggar aturan adat saat berada di hutan. Oleh karena penyakit tidak juga sembuh, Undat harus dibawa pulang ke kampung halamannya. Parhan bertugas mengantar Undat pulang. Parhan menerima tugas tersebut dengan senang hati karena dia dapat pulang menjenguk istri dan anaknya. Setelah mengantar Undat ke keluarganya, Parhan mendatangi rumahnya. Betapa terkejutnya ia ketika mendapati istrinya, Imas sedang berduaan dengan Pak Joh di kamar mereka. Dalam keadaan kalap, Parhan mencabut mandau yang ada di dinding dan mengayunkannya pada Imas dan Pak Joh. Kedua orang itu seketika meninggal dunia.

Cerita kedua adalah "Poniran" karya Muthi' Masfuah yang berlatar belakang tahun 1980-an. Cerita tersebut menceritakan tokoh utama bernama Poniran seorang rakyat biasa yang termasuk masyarakat marginal. Poniran adalah seorang rakyat jelata yang menyambung hidup dengan berjualan taoge. Pendapatannya dari berjualan taoge tidaklah besar. Dengan penghasilannya yang 
sedikit itu, ia harus menghidupi anak dan istrinya. Sebagai rakyat kecil, Poniran seringkali mengalami kesialan hidup yang disebabkan oleh kemiskinannya. Suatu hari ia tidak dapat berjualan karena kakinya tertusuk paku berkarat. Karena ia tidak berjualan dalam satu hari, modalnya yang sedikit langsung habis untuk biaya keperluan sehari-hari. Ditambah lagi, Poniran tidak memiliki uang untuk berobat. Untuk itu, ia harus meminjam pada rentenir dengan bunga yang sangat tinggi. Poniran sangat sedih memikirkan hal itu, tetapi ia tidak punya pilihan lain. Sebagai rakyat kecil, ia meyadari bahwa hidupnya tidak seberuntung orang-orang kaya. Ia pernah tergiur tanah murah di pinggiran kota. Ia kemudian memboyong keluarganya ke sana. Namun kemudian, tanahnya digusur karena tidak bersertifikat. Poniran dan keluarganya harus pindah ke tempat yang lain. Poniran tetap melanjutkan hidupnya berjualan taoge. Ia berharap istri dan anak-anaknya tidak seperti orang-orang yang terpengaruh gemerlapnya zaman. Ia bercita-cita mewujudkan kepedulian terhadap sesama yang dimulai dari keluarganya.

Cerita pendek yang terakhir adalah "Kota ini telah Terjual" karya Jumri Obeng yang dimuat di mingguan Minggu Merdeka, 7 Mei 1978. Tokoh utama cerita pendek ini adalah seorang lelaki tua yang tinggal di sebuah daerah kecil bernama Loa Kulu. Daerah itu sekarang menjadi bagian dari Kabupaten Kutai Kartanegara, yaitu Kecamatan Loa Kulu. Daerah itu pada masa pemerintahan Belanda merupakan daerah penghasil batu bara yang sangat penting. Cerita pendek "Kota ini telah Terjual" menceritakan daerah Loa Kulu, yang telah menjadi daerah yang lengang. Para pekerjanya diberhentikan secara bertahap karena produksi batu bara dihentikan setelah nilai jualnya di negara-negara industri merosot.
Seorang lelaki tua diceritakan bersedih lantaran daerah yang menjadi kebanggaannya selama ini telah berubah jadi semacam kota hantu yang gelap dan sepi. Lelaki tua tersebut mengingat kembali kejayaan kotanya dulu. Dahulu ia bangga sekali dan gembira tinggal di daerah penghasil batu bara. Akan tetapi, keadaan sudah berubah ketika batu bara sudah habis, daerah tersebut mulai sepi karena ditinggalkan pekerja yang selama ini meramaikan Loa Kulu. Pada saat yang bersamaan, sebuah perusahaan asing yang bergerak di bidang perkayuan telah berdiri di daerah Loa Kulu. Awalnya perusahaan asing tersebut berjanji akan menyediakan fasilitas penerangan, pendidikan, dan jalan sebagai sarana transportasi bagi penduduk di sekitar. Perusahaan itu juga berjanji akan mengganti kerugian yang cukup besar untuk rumah-rumah rakyat yang terkena dampak penggusuran dan menampung tenaga kerja dari penduduk setempat. Perusahaan asing itu juga berjanji akan membuat sebuah jalan utama yang mulus beraspal. Namun, janjijanji tersebut tidak sesuai dengan kenyataannya. Fasilitas listrik hanya ada di sekitar komplek perusahaan dan tidak terdapat di jalan umum yang menghubungkan kampung hulu dan hilir. Perekrutan tenaga kerja lebih banyak didatangkan dari ibukota provinsi, sedangkan penduduk setempat hanya sebagai pekerja kasar yang dibayar secara harian. dengan upah Rp400,00. Akhirnya, lelaki tua bersama penduduk berniat membuat resolusi kepada bupati agar membantu realisasi janji-janji perusahaan tersebut bagi kepentingan penduduk setempat. Sebelum resolusi terlaksana, lelaki tua yang mengusulkan ide resolusi menghilang. Di akhir cerita, lelaki tua itu muncul dan duduk di pinggir sungai. Di bagian pelipis dan keningnya terlihat dua buah bekas luka. Luka-luka itu masih biru dan mengeluarkan darah yang kental. Ia tidak lagi berniat melanjutkan resolusinya. 


\section{Resistansi Tokoh}

\section{a. Bentuk Resistansi Terbuka}

Resistansi terbuka terjadi karena penyebab secara langsung seperti penindasan, ancaman, tekanan, paksaan yang dilakukan oleh tuan tanah, pemerintah, pemilik modal atau pihak lain. Dalam cerita pendek "Banjirkap" dapat dilihat bahwa tokoh Parhan mendapat penindasan yang dilakukan secara langsung dihadapannya, yaitu perselingkuhan pak Jo dan Istrinya. Parhan tetaplah seorang laki-laki yang tidak dapat menahan amarahnya mendapati istrinya telah berselingkuh dengan Pak Joh, pemilik modal tempatnya bekerja. Hatinya sakit karena kesetiaan yang selama ini dipertahankannya telah dikhianati oleh istrinya.

Sebagai reaksi dari penindasan yang ia dapatkan, Parhan melakukan perlawanan secara terbuka. Resistansi atau perlawanan terbuka adalah bentuk perlawanan yang dilakukan secara terbuka yaitu dapat diamati dan bersifat konkret (Susilowati 2019:7). Tokoh Parhan dalam cerita "Banjirkap" secara langsung melakukan perlawanan yang dapat dilihat secara konkret, yaitu berusaha membunuh Pak Joh dan istrinya menggunakan mandau.

Tanpa harus mengotak-atik tanya, aku segera memahami apa yang terjadi. Begitu juga sewaktu mataku singgah pandang pada mandau tampilan yang tergantung di dinding dekat kamar, aku juga maklum apa yang harus dilakukan. Mandau warisan kakek yang pernah digunakan membunuh serdadu Jepang pada zaman penjajaha, selama ini hanya menjadi hiasan dinding. Menjadi pajangan. Ketajaman mandau tampilan itu melebihi mandau yang biasa digunakan bekerja di hutan.
Tanpa membuang waktu aku meloncat dan menyambar mandau tersebut, disertai teriakan histeris Imas yang berusaha menjaga langkahku. Mandau warisan itu kuhunus dari sarungnya. Kuayunkan dengan segenap tenaga seorang pembatang. Dalam hitungan detik, cairan merah menyembur membasahi kamar tidur dan ruang tengah. Dua tubuh terkapar, Pak Joh dan Imas roboh menggelepar. (Asyari, 2011:628).

Resistansi terbuka juga didapati dalam cerita "Kota ini telah Terjual". Cerita ini menunjukkan bahwa lelaki tua dan penduduk dalam cerita ini telah berusaha melakukan perlawanan konkret berupa protes atau resolusi. Untuk kepentingan masyarakat yang ia cintai, lelaki tua dalam cerita tersebut berusaha membuat suatu gerakan agar penduduk setempat lebih diperhatikan. Bersama beberapa penduduk setempat ia berniat mengajukan resolusi kepada bupati agar lebih memperhatikan nasib masyarakat Loa Kulu.

Dijawab, “Kita harus membuat resolusi yang ditujukan kepada bupati agar kota kita ini bukan saja dijadikan sumber pencaharian orang-orang nonpribumi, tapi lebih daripada itu kita menginginkan agar dapat merasakan betapa nikmatnya hidup di tanah air sendiri. Kita menuntut janji-janji tentang gedung SMP, tentang lampu-lampu listrik, jalan beraspal, dan juga janji tentang diperhatikannya nasib-nasib penganggur di kota ini. Itu saja yang kita minta sebagai imbalan dari nikmat tanah air kita yang telah mereka kuras dan sedot" (Obeng, 1978). 


\section{b. Bentuk Resistansi Tertutup}

Resistansi tertutup menurut Scott (dalam Susilowati, 2019:5) merupakan bentuk perlawanan yang dilakukan secara tertutup yang bersifat simbolis dan ideologis. Resistansi simbolis biasanya dilakukan dengan tindakan-tindakan seperti gosip, fitnah, atau mengumpat dalam hati. Resistansi ideologi berupa penolakan terhadap ideologi atau prinsip-prinsip yang dipaksakan kepada masyarakat dan serta penarikan kembali rasa hormat kepada pihak penguasa. Resistansi tidak langsung dilakukan melalui perlawanan yang dilakukan secara sembunyisembunyi untuk mencapai hasil lebih besar dibandingkan resistansi yang dilakukan secara terang-terangan.

Resistansi tertutup dalam "Banjirkap" adalah sikap Parhan menolak ajakan temantemannnya untuk mencari wanita penjaja cinta. Menjadi seorang penebang juga tidak menyenangkan, apalagi selama berbulanbulan Parhan harus berpisah dengan istrinya. Parhan termasuk laki-laki yang setia terhadap istrinya. Sebagai laki-laki dewasa berusia 35 tahun, ia dapat mengendalikan hasrat biologisnya. Ia tidak terpengaruh temantemanya yang sering melampiaskan hasrat biologisnya pada penjaja cinta di Kampung Muara.

Dalam kondisi jauh dari sisi sang istri, seringkali teman-teman sekerja menghadirkan cerita memuakkan. Cerita tentang pelayanan wanita jalang yang mereka gauli sewaktu berada di Kampung Muara. Mereka tak sungkan bicara tentang payudara, puting, bokong, pipi berpupur tebal, dan bibir bergincu menyala. Selanjutnya dibumbui cerita tentang goyangan pinggul, pagutan mesra, dan hal-hal lain yang mengundang sensasi liar. Sungguh cerita memuakkan. Meskipun pada akhirnya berubah menjadi gelinjang goda yang tiada tertahankan (Asyari, 2011:621).

Penolakan yang dilakukan Parhan bukanlah penolakan terang-terangan. Parhan hanya diam dan mengikuti ajakan temantemannya ke tempat wanita penjaja cinta, tetapi hatinya melakukan penolakan. Resistansi tertutup Parhan menyebabkan ia tidak melakukan apa-apa di kamar Sumi, wanita penjaja cinta.

Lopat! Pertahananku hampir bobol. Tapi ketika Undat menyebut "istrimu" mendadak aku terjengah. Aku ingat Imas, istri yang kutinggalkan bersama putri kami, Jurai. Anak semata wayang. karena itulah sewaktu masuk ke kamar Sumi, wanita yang menjadi pilihanku, aku pun hanya mengajak berbincangbincang (Asyari, 2011:621).

Resistansi tertutup dapat ditemukan dalam cerita pendek "Poniran". Sebagai masyarakat kecil tokoh Poniran sangat memahami posisinya yang tidak mungkin protes tentang ketidakadilan yang diterimanya. Perlawanan yang dilakukan Poniran berupa manajemen dirinya untuk menerima segala ketimpangan yang diterimanya. Sebagai rakyat kecil, Poniran tahu bahwa tidak ada yang peduli pada kemalangannya. Rakyat kecil bukanlah bagian terpenting dalam kehidupan masyarakat. Keberadaannya seringkali terlupakan dan terpinggirkan. Dengan mengumpulkan sedikit demi sedikit uang hasil berjualan, Poniran dapat membeli tanah murah yang letaknya di pinggir kota. Akan tetapi, tanahnya diambil alih pemerintah dengan alasan tidak memiliki sertifikat. Poniran tidak pernah berusaha untuk melakukan protes karena tanahnya diambil pemerintah. Resistansi yang dilakukan Poniran adalah mengajak 
anak istrinya untuk mencari tempat tinggal di lain tempat sambil melanjutkan hidupnya.

Namun kemudian, tanahnya digusur karena tidak bersertifikat. Poniran dan keluarganya harus pindah ke tempat yang lain. Poniran tetap melanjutkan hidupnya berjualan taoge (Masfuah, 2001).

Pada saat ia terkena musibah terkena paku yang membuat kakinya infeksi sampai ia tidak dapat bekerja berjualan taoge, Poniran memilih untuk diam dan tidak melakukan protes. Ia justru memilih untuk berjuang sendiri memenuhi kebutuhannya dengan meminjam uang pada rentenir.

Ditambah lagi, Poniran tidak memiliki uang untuk berobat. Untuk itu ia harus meminjam pada rentenir dengan bunga yang sangat tinggi. Poniran sangat sedih memikirkan hal itu, tetapi ia tidak punya pilihan lain. Sebagai rakyat kecil, ia meyadari bahwa hidupnya tidak seberuntung orang-orang kaya (Masfuah, 2001).

Resistansi yang dilakukan Poniran dalam mengatasi persoalan hidupnya adalah berdoa kepada Tuhan agar keluarga dan anaknya memiliki kepedulian sosial. Ia menginginkan keluarganya hidup dalam kejujuran dan tidak menyengsarakan kehidupan orang yang lain. Ia berharap bahwa anak-anaknya kelak menjadi manusia yang peduli pada sesama.

Poniran sekali lagi, tak ingin anak-istrinya menjadi individual. Ya, dari keluarganya ini, ia akan memulainya. Sebuah cita-cita luhur dari seorang Poniran, si orang kecil (Masfuah, 2001).
Resistansi tertutup yang terdapat dalam terdapat dalam "Kota ini telah Terjual" dilakukan oleh tokoh lelaki tua yang awalnya berusaha untuk melakukan protes atas janji-janji perusahaan kayu kepada warga yang tidak ditepati. Setelah penganiayaan yang diterimanya akibat usulan protes kepada bupati yang dilontarkannya, ia memilih untuk tidak melakukan tindakan frontal. Ia memilih untuk hanya menolak di dalam hatinya sambil memasrahkan persoalan tersebut pada waktu.

\begin{abstract}
"Apakah kita gagal membuat resolusi?" tanya wali dusun. Dan sambil menyapu sudut mata dengan telapak tangannya, lelaki tua itu pelan-pelan menjawab: "Aku tidak ingin tulang pelipisku rusak buat yang kedua kalinya. Jadi lebih baik kita menunggu saja kapan kebenaran dan moral bisa ditegakkan di kota kita ini" (Obeng, 1978).
\end{abstract}

Tiga cerita pendek, yaitu "Banjirkap", "Poniran" dan "Kota ini telah Terjual" memerikan beberapa bentuk resistansi, baik terbuka maupun tertutup. Resistansi terbuka dilakukan oleh Parhan, tokoh dalam cerpen "Banjirkap". Perlawanan tersebut merupakan perlawanan frontal yang dilakukan tanpa berpikir dua kali, sehingga hasilnya merugikan banyak orang. Sementara itu, tokoh aku dalam "Kota ini telah Terjual" juga berencana melakukan perlawanan terbuka berupa aksi protes atau resolusi terhadap bupati dan pimpinan perusahaan kayu. Namun, sebelum aksi tersebut berlangsung, tokoh aku menghilang. Perbedaan yang terdapat dalam dua macam resistansi tersebut adalah pada waktu pelaksanaannya. Resistansi yang dilakukan Parhan langsung dilakukan pada saat itu juga, yang berakibat kerugian bagi semua pihak. Sementara resistansi terbuka yang dilakukan tokoh aku 
dalam "Kota ini telah Terjual" menunggu waktu yang tepat dalam pelaksaannya. Hal itu berakibat penguasa memiliki waktu untuk melakukan intimidasai pada tokoh aku. Kedua macam resistansi terbuka tersebut tidak menguntungkan bagi tokoh yang melakukan perlawanan.

Berbeda halnya dengan resistansi terbuka yang terdapat dalam ketiga cerita pendek tersebut. Bentuk resistansi tertutup yang dilakukan Parhan ketika dipaksa temantemannya untuk ikut ke tempat pelacuran mampu memperbaiki keadaan tanpa merugikan pihak manapun. Hal itu juga berlaku pada tokoh Poniran dalam cerpen "Poniran" dan tokoh aku dalam "Kota ini telah Terjual". Walaupun secara materi dan fisik kedua tokoh tersebut mengalami kerugian, tetapi kerugian tersebut tidak sebanyak apabila mereka melakukan resistansi secara terbuka.

\section{Penyimpangan Kekuasaan dalam "Banjirkap", "Poniran" dan "Kota ini telah Terjual"}

Resistansi yang dilakukan tokoh Parhan, dalam "Banjirkap", Poniran dalam "Poniran", Lelaki Tua dalam "Kota ini telah Terjual" adalah sebagai bentuk kontra dari adanya penyimpangan kekuasan yang dilakukan pemegang kekuasaan. Dalam "Banjirkap", pemegang kekuasaan adalah tokoh Pak Joh dan Imas. Pak Joh adalah pemilik modal yang membeli kayu-kayu hasil tebangan para penebang kayu. Pak Joh akan menjual kayukayu tersebut dengan harga jauh lebih tinggi. Karena tahu akan mendapat untung yang banyak, Pak Joh tidak segan-segan untuk meminjamkan uang dan memenuhi kebutuhan keluarga para penebang kayu. Pinjaman tersebut akan dipotong dari pendapatan para penebang. Sebagai tengkulak, Pak Joh mendapat untung yang sangat banyak tanpa harus mengerahkan tenaga seperti para penebang.
Sang anemer yang membiayai kami, memiliki keuntungan berlipat ganda karena kayu yang dijual kepada pengusaha asing harganya sangat tinggi. Karena itulah tak heran Pak Joh berani mengeluarkan biaya besar selama berbulan-bulan untuk kami (Asyari 2011:622-623).

Parhan sebetulnya menaruh hormat pada Pak Joh karena kebaikannya. Selain memberikan pinjaman uang untuk para penebang, Pak Joh juga memberi perhatian kepada keluarga para penebang. Perhatian itu dalam bentuk melayani pengiriman surat para penebang untuk keluarganya dan sebaliknya. Akan tetapi, perhatian Pak Joh ternyata tidak hanya sebatas itu. Ia telah menyalahgunakan kepercayaan para penebang, terutama Parhan, dengan cara bermain api dengan Imas.

Hups! Aku kaget. Di tempat tidur, di atas ranjang besi Nampak seorang lakilaki bertelanjang dada. Meski remangremang, namun aku bisa mengenali laki-laki itu. Dia adalah Pak Joh, anemer kami. Pak Joh segera bangun dan ingin menghindar. Tapi tidak mungkin keluar karena terhalang tubuhku yang berdiri di ambang pintu (Asyari 2011:628).

Penyimpangan kekuasaan dilakukan Pak Joh, yaitu anemer yang dihormati Parhan. Pak Joh telah menyalahgunakan kepercayaan Parhan yang menjadi penghubung Parhan dan istrinya selama ia bekerja di hutan.

Pemegang kekuasaan lainnya dalam "Banjirkap" adalah Imas, istri Parhan. Selama bekerja di hutan, Parhan menyerahkan kekuasaan rumah tangganya kepada Imas. Ia berharap Imas mampu menjaga kepercayaannya dengan mengelola rumah tangga- 
nya secara baik. Namun, kepercayaan Parhan pada Imas juga disalahgunakan.

Kembali aku mengetuk pintu dengan hati-hati. Beberapa jurus kemudian terdengar suara langkah kaki menuju pintu. sesaat pintu itu pun terkuak. Wajah Imas yang kurindukan menyembul dari balik pintu kayu yang terbuka pelan. Sesaat Imas terpana.

"Kakak...kak Parhan sudah pulang? Ken.. kenapa tidak memberi kabar?"

Sekilas ada getar kegugupan dari suara Imas. Namun, aku pikir itu hanyalah lantaran rasa kaget karena dia tak menduga kami akan bisa bertemu lebih cepat (Asyari 2011:628).

Pemegang kekuasaan dalam cerpen kedua, yaitu "Poniran" adalah pemerintah yang tidak memiliki kepedulian terhadap rakyat kecil seperti Poniran dan keluarganya. Poniran dan keluarganya adalah golongan masyarakat miskin yang tidak memiliki jaminan kehidupan, baik itu kesehatan maupun kesejahteraan. Apabila ia mengalami musibah, tidak ada yang menjamin pengobatan dan kesejahteraan keluarganya. Tanah yang telah dibeli dari menyisihkan uang hasil jualan diambil pemerintah karena tidak ada sertifikatnya. Pemerintah tidak memikirkan nasib Poniran dan keluarganya yang harus pindah mencari tempat tinggal baru.

Belum bernafas lega, tanahnya malah digusur dengan dalih tak besertifikat. Kini ladangnya pun dijadikan lapangan golf, rumahnya kini jadi gedung bioskop. Karena penguasa yang minta, Poniran jadi tak kuasa. Bila menolak, alamat pasti celaka! (Masfuah, 2001).
Pemerintah dalam cerita "Poniran" adalah contoh pemegang kekuasaan yang melakukan penyimpangan keuasaannya. Pemerintah tidak melindungi warganya yang tidak memiliki daya dalam kehidupannya atau termarginalkan seperti Poniran dan keluarganya.

Pemegang kekuasaan dalam cerita "Kota ini telah Terjual" adalah bupati dan perusahaan kayu. Mereka melakukan penyimpangan kekuasaan dengan cara melakukan intimidasai terhadap lelaki tua yang berniat resolusi atas janji perusahaan kayu yang tidak ditepati. Intimidasi yang dilakukan berupa penculikan, penyekapan, dan penyiksaan tokoh lelaki tua.

Namun, setelah mengalami penculikan, lelaki tua ini berubah. Ia tidak lagi penuh semangat memperjuangkan kota yang dicintainya. Ia tidak lagi peduli nasib penduduk di kotanya. Ia terlihat lebih memikirkan nasibnya sendiri (Obeng, 1978).

Para pemegang kekuasaan dalam tiga cerita pendek melakukan penyimpangan dengan menyalahgunakan kekuasaan mereka. Sebagai pemegang kekuasaan yang dipercaya untuk mengatur kehidupan beberapa orang di bawahnya, mereka seharusnya menjalankan kewajiban dengan amanah, yaitu memenuhi hak-hak masyarakat yang menjadi tanggung jawabnya. Namun, mereka justru menindas dan mengintimidasi masyarakat untuk kepentingan mereka sendiri.

\section{PENUTUP}

Tiga cerita pendek, yaitu "Banjirkap", "Poniran" dan "Kota ini telah Terjual" merupakan tiga cerita pendek Kalimantan Timur yang memuat penyimpangan kekua- 
saan dan resistansi tokoh terhadap penyimpangan kekuasaan. Resistansi yang terdapat dalam cerita "Banjirkap" adalah resistansi terbuka dan tertutup yang dilakukan tokoh Parhan. Resistansi terbuka dilakukan ketika melihat istrinya dan Pak Joh berselingkuh. Sementara itu, resistansi tertutup dilakukan Parhan terhadap ajakan teman-temannya untuk melampiaskan hasrat biologis melalui wanita penjaja cinta.

Resistansi dalam cerita pendek "Poniran" adalah resistansi tertutup yang dilakukan tokoh Poniran. Poniran memilih untuk menyingkir dari permasalahan dari pada melakukan perlawanan frontal. Hal itu dilakukannya pada saat tanah yang dibelinya diambil pemerintah dengan alasan tidak ada sertifikatnya. Poniran memilih mencari tempat tinggal lain daripada protes kepada pemerintah. Perlawananya dilakukan dengan mengharap kepada Tuhan agar anak-anaknya memiliki kepedulian terhadap masyarakat kecil.

Resistansi yang terdapat dalam "Kota ini telah Terjual" adalah resistansi terbuka dan tertutup. Tokoh lelaki tua melakukan perlawanan terbuka dengan cara meresolusi atas janji penguasa yang tidak ditepati. Ia juga melakukan perlawanan tertutup dengan cara hanya menolak di dalam hatinya sambil memasrahkan persoalan tersebut pada waktu. Hal itu dilakukan setelah ia mengalami penculikan dan penyiksaan.

Cerpen-cerpen tersebut menunjukkan relasi kekuasaan adalah suatu bentuk legalitas yang digunakan oknum tertentu untuk menindas masyarakat marginal. Namun, sebetulnya kekuasaan memiliki ikatan saling menguntungkan dengan masyarakat agar terwujud keharmonisan dan kesimbangan.

\section{DAFTAR PUSTAKA}

Asyari, Habolhasan. 2011. "Banjirkap" dalam Korrie Layun Rampan, ed. Kalimantan Timur dalam Sastra Indonesia. hlm. 620-629. Samarinda: Panitia Dialog Borneo XI bekerjasama dengan Dinas Pendidikan provinsi Kalimantan Timur.

Faruk. 1994. Pengantar Sosiologi Sastra. Yogyakarta: Pustaka Pelajar.

Goldmann, Lucien. 1970. “The Sociology of Literature: Status and Problems in Methods". Dalam Milton C. Albrecht cs. (eds), The Sociology of Art and LiteratureNew York: Praeger Publisher. Kotijah, Siti. 2010. “Banjr Kap Batubara Kaltim". Dalam Slamet Hariyanto dan Rekan, Gagasan Hukum.

https:/ / gagasanhukum.wordpress.com/ 2010/03/18/banjir-kap-batubarakaltim/diakses 12 November 2019

Masfuah, Muthi'. 2001. "Poniran" Kaltim Post 8 April.

Obeng, Jumri. 1978. "Kota in telah Terjual" Minggu Merdeka, 7 Mei.

Ratna, Nyoman Kutha. 2008. Teori, Metode, danTeknik Penelitian Sastra. Yogyakarta: Pustaka Pelajar.

Scott, James C. 2000. Senjatanya Orang-Orang Yang Kalah. Jakarta: Yayasan Obor Indonesia.

Sulistyo dan Basuki. 2006. Metodologi Penelitian. Jakarta: Penerbit Wedatama Widya Sastra Fakultas Ilmu Pengetahuan Budaya Universitas Indonesia. Susilowati, Enik Zuni dan Titik Indarti. 2019. "Resistensi Perempuan dalam Kumpulan Cerita Tandak Karya Royyan Julian (Teori Resistensi-James C. Scott) dalam Jurnal Bapala. Semarang: Prodi Pendidikan Bahasa dan sstra Indonesia, Universitas Negeri Semarang. 
Zuraida, 2013. "Perlawanan Perempuan Mesir Terhadap Dominasi Laki-laki dalam Novel Lail Wa Qudhbihi Karya Najib Al-Kailanni" (http:/ / etd.repository.ugm.ac.id/index.php/ wacana/article/view File/3638/2893) diakses pada tanggal 14 November 2019. 